\title{
標本抽出による群落测定 ${ }^{*}$
}

\author{
沼田 真** \\ Makoto NumATA: The investigation of vegetation by means of sampling \\ method-Studies on the structute of plant communities V.
}

\section{\&1.はしがを}

槽本抽出法，とくに小標本によつて群落調䄳党行う場合に注意すべき二三の問題について

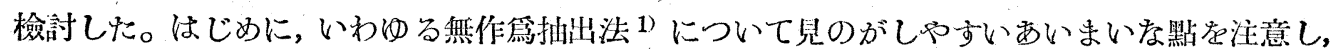
しかるのちこの方法の一つの基礎になる屋分け stratification につきまをう諸問題を野外のデ 一タにもと佶て考察した。

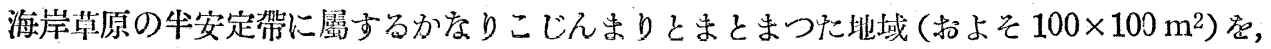
主として相覞によつて 5 つ區 stratum にわけ, その招の扮のを $1 \mathrm{~m}^{2}$ の小さな柝 quadrat (cell) に仕切り，しかるのち，(I) その中から任意に2この抽出單位 sampling unit をえら ぶ。 1 抽出單位は $1 \mathrm{~m}$ 扣きに連續した 5 この枓 plot ( $1 \mathrm{~m}^{2}$ quadrat) からなる。 (II) 扣の

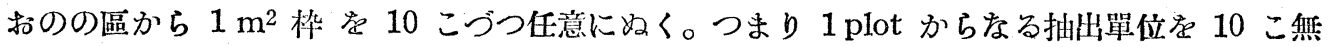
作爲にとることになる。（III） 5 つの區を一緒にして, 全地區を $1 \mathrm{~m}^{2}$ の枓に仕切り, その中 から無作䉆抽出を守る。以上 3 つの方法存用い, 主として被度と密度密测度 measure として 調查在行つた。

野外調查は 1949 年 8 月, 千葉縣長生郡東浪見村海岸砂原において行われな。この間, 香

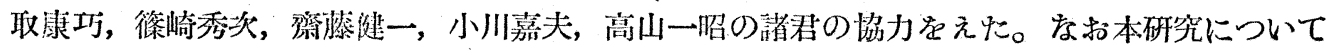
助言定與えられた統計數理研究員白石一誠氏に對して感謝する。

\section{\& 2. 標本抽出法}

植物群落の定量的な解析法は, 今世紀に入つてから急速な進展学みせた。その發端をなし たのは Pound and Clements $の$ quadrat method ${ }^{2)} \varepsilon$ Raunkiaer $の$ frequency method ${ }^{3)}$ とで西ろう。以來, 群洛测定に用いる测度として, 頻度率, 被度, 密度などがとりる隹られ, 他にも群度その他の計量化しにくいいくつかの樌識が用いられた。

また一方, 枠法の發展は必然的に, 群落测定点標本調查 sampling survey たらしめるに 至つたが，ときには du Rietz一派のように，それが有意選出 objective choice にもと和 て扣り，また，他の多くの昜合のように無作雼抽出 random sampling が標榜されても, 實 際には主觀的な randomization で，客觀的なそれになつていなかつたことが多かつた。とい

* 日本植物學會第 15 回大會 (名古屋) で講演した。昭和 24 年度交部省科學研觉費交附金飞よる研究 の一部。

** 千葉大學文理學部, 東京文理科大學植物學敉室。 


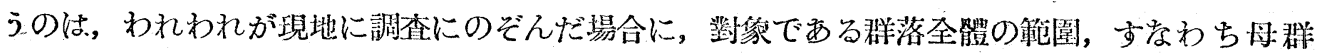
落 “ universe” of plant community の全貌が明確にとらえられていない。泍学無作鹪抽出 して野外調查を行うといいながらも, “全體”と對決されていない“部分”では, 部分という

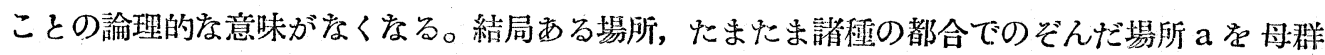

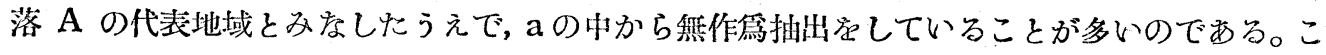
の場合，もしａの選摆が正しくをければ，そこには有意選出の誤りが混入してくる。今日にお。 いて林學，農學方面のいくつかの例をの炎けば，群落學的存野外調查において，原则的には, 多

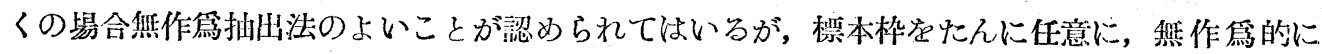

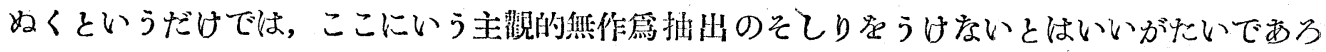
j。

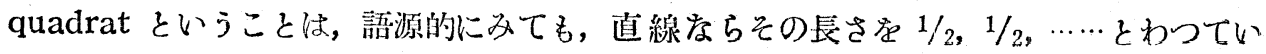
くこと, 平面ならその面積を $1 / 4,1 / 4, \cdots \cdots$ わつついくことを西らわしている。群洛調查に招 いては後者のようにして, 群落の占める地積存逐次細かく分けていらて, 全體の何分の一かに 想當するいわゆる quadrat（統計學でいう cell）学若干個(これが標本の大いさ $N$ ) 抽出し て，それから全體を推定しょうとするわけでする。

\section{3. 抽出誤差による方法の比較}

同一の群落在調査しようというのに, 前に示した (I), (II) いすれの方法がすぐれている かを論するために，植被率 4)（程類ごとの被度でなく，一枓中の植物被覆全體の占わる百分率 をこのようによぶ）在測度とし，抽出柝の植被率の平均值 $\bar{x}$ と抽出誤差 $s . e .=S / \sqrt{N}$ を算出 し，な扬 s.e. が $\bar{x}$ の何\%にあたるか（s.e.\%で西らわす）在計算した（但し $S, N$ はそれ ぞれ標本標準偏差, 栖本の大いさを示す)。さらに參考のため, 植被率を測度として 群落の均 質度係數 (植被均質度係数) ${ }^{5)} \cdot h$ $=d / \bar{x}$ 算出した。

この結果 (Table 1.) からみ ると，抽出誤差の大いさは，主な 原因として第一に植被均質度に， 第二に抽出比 $(A: 1 / 300, B: 1 / 260$, $C: 1 / .70, D: 1 / 135, E: 1 / 240) に も$ すくと思われる。拍出比を等しく 専れば，扣そらく主に植被均質度 によつて抽出誤差は左右されるで あろう。

群落調查において抽出誤差の 大いさ在 $10 \%$ 程度までゆるすと すれば,このような植被均質度㾜 もつた群落において，この程度の 抽出比ではいす机の力法によつて

Tabie 1. The comparison of two methods by means of sampling error

\begin{tabular}{|c|c|c|c|c|c|c|}
\hline Method & $\begin{array}{l}\text { Strat- } \\
\text { um } \\
\text { asure }\end{array}$ & A & B & C & D & $\mathrm{E}$ \\
\hline \multirow{4}{*}{ I } & $\left.\bar{x}^{1}\right)$ & 36.9 & 21.6 & 5.7 & 13.3 & 19.1 \\
\hline & s.e. & 5.74 & 7.77 & 1.20 & 4.40 & 4.06 \\
\hline & s.e. $\%$ & 15.6 & 36.0 & 21.1 & 33.1 & 21.3 \\
\hline & $h^{2)}$ & 1.12 & 1.22 & 1.48 & 2.46 & 1.52 \\
\hline \multirow{4}{*}{ II } & $\bar{x}$ & 51.0 & 17.4 & 5.2 & 9.5 & 19.4 \\
\hline & s.e. & 9.15 & 3.55 & 1.77 & 3.70 & 2.67 \\
\hline & s.e.\% & 17.9 & 20.4 & 34.0 & 38.9 & 13.8 \\
\hline & $h$ & 1.37 & 1.46 & 3.25 & 2.67 & 0.78 \\
\hline
\end{tabular}

1) The average number of percentage of vegetational

2) coefficient ot vegetational homogeneity 
も不十分であると思われる。しかも總括的に (I), (II) 兩方法の優劣はつけがたいことが知ら れるであうう。

\section{4. 層分けの辰さの推定}

この海岸群落の畨分けにおいては，前記のように5この屡（區）を區別したので西るが， 果してこの上うな分け方がよいのであるか，または前節のごとく(I) と（II）いすれの方法が すぐれているか在制定しようというような場合に，級內相䈘係數 ${ }^{6)}$ coefficient of interclass correlation $\left(\rho^{\prime}\right)$ 在利用することができるであるう。すなわち

$$
\rho^{\prime}=\left\{\sigma_{b^{2}}-\frac{\sigma_{w}^{2}}{k-1}\right\} \frac{1}{\sigma^{2}},-\frac{1}{k-1} \leqq \rho^{\prime} \leqq 1
$$

ここで $\sigma_{b}{ }^{2}$ は級間分散, $\sigma_{w}^{2}$ は級內分散, $\sigma^{2}$ は全分散, $k$ は級の數である。

母集團 $(A+B+C+D+E)$ をいくつかの區 (family 西るいは stratum) に分けたときに, その各區の中での均質の程度によつて $\rho^{\prime}$ の值がかわつてくる。すをわら 1) $\sigma_{w}=o, \sigma=\sigma_{b}$ の とき $\rho^{\prime}=1$ で展分けはこのとき最高の威力在發挥与る。 $-\frac{1}{k-1}$ で, 集落抽出 cluster sampling の場合にはこれがもつともよいことになる。こうし

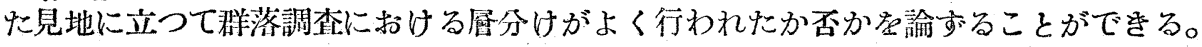

相萑的に分けられた各區疮 stratum でなくて cluster とみなした場合，もし各構成㮔の 組成比が母集團全體にわたつて陑めて均質で西るとすれば, $A, B, C, \cdots \cdots$ の小れの區をとつ ても一つの代表的な cluster と立ることがでをる。ところが賽際にはかなり不均質な組成をも つているので，上記の計算によつて，㞕分けとして一番よいと考えられな方法は集落化として は一番不適當であり, 前者の良さの順位は後者の惡さの順位として現れるであるうと考えられ る。なお測度としては平均被度究用いた。

そこでいま stratum あるいぬ cluster として, $\stackrel{\circ}{1}: A, B, C, D, E ; \stackrel{\circ}{2}: A, B+C, D+E:$ $\stackrel{\circ}{3}: A, B+D, C+E ; \stackrel{\circ}{4}: A, B+C+D+E ; \stackrel{\circ}{5}: A / 2+B+D, A / 2+C+E$ のつの grouping

Table 2. The comparison of several stratifications at a coastal vegetation by means of coefficient of interclass correlation.

\begin{tabular}{c|c|c|c|c}
\hline $\begin{array}{c}\text { Method } \\
\text { of } \\
\text { stratification }\end{array}$ & $\sigma b^{2}$ & $\sigma_{w^{2}}$ & $\sigma^{2}$ & $\rho^{\prime}$ \\
\hline$\circ$ & 2.75 & 20.61 & 23.36 & 0.0197 \\
$\circ$ & 3.60 & 27.16 & 30.76 & 0.0188 \\
2 & 3.55 & 29.76 & 29.98 & 0.0081 \\
$\circ$ & 3.96 & 37.23 & 41.20 & -0.0043 \\
$\circ$ & 0.03 & 5.96 & 5.97 & -0.1058 \\
\hline & & &
\end{tabular}

$\sigma b^{2}$ : variance between classeb, $\sigma_{w}^{2}$ : variance within classes, $\sigma^{2}$ : total variance, $\rho^{\prime}$ : coefficient of interclass correlation. 
そつくつてそれらの比較安行つてみた。標本抽出によつてとらえられた構成種はケカモノハシ, オニシバ, コーボーシバ, オーアレヂノギク，イガガヤッリ，ヒメクグ，チガヤ，八マヒルガ オ, ピロードテンツキ, ハマニガナの 10 種で, 各區內におけるこれらの星的組成が群落全體 にわたつてどの侱度均質であるかをみようとするわけである。その結果は Table 2. の上うに なる。したがつて屡分けの良さの順位は $1>2>3>4>5$ (集落化の良さの順位はこの逆）とな

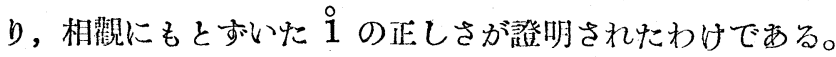

な扣前に抽出誤美によつては何ともいえなかつた（I)，(II）の方法の優劣に關して，それ

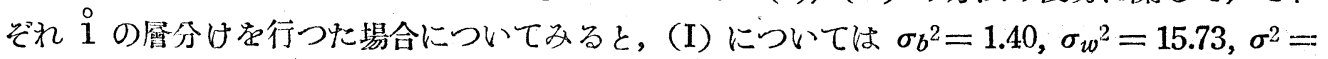
17.17 で $\rho^{\prime}=-0.0329$ となり, (II) の場合の $\rho^{\prime}=0.0197$ よりなり小さい。つまり (II) 1 で $\rho^{\prime}=0.0197$ 程度の均質性杂示しているのに，(I) 迄でれれが實情にそうように捉えられ ていないことになり，方法的に（II）の方がまさつていると考えられる。

\section{\& 5. 優占種による層分け}

級內相關係數は級內の類似度あるいは一樣性を問題にするので，優占種であるらカモノ八 シだけを目安として群落の均質性の整度を测りうるかどうかが開題となる。そこで虽分けは前 記の 1〜过の方法, 標本抽出は (I) によつて調べでみると Table 3.のようになる。この結果

Table 3. The comparison of several stratifications by a dominant at a coastal vegetation.

\begin{tabular}{c|c|c|c|c}
\hline & $\sigma b^{2}$ & $\sigma_{w}^{2}$ & $\sigma^{2}$ & $\rho^{\prime}$ \\
\hline$\circ$ & 54.98 & 58.46 & 133.44 & 0.363 \\
$\circ$ & $56.9:$ & 4752 & 104.42 & 0.494 \\
$\circ$ & 47.66 & 41.11 & 88.76 & 0.485 \\
\hline & 52.49 & 43.11 & 95.60 & 0.500 \\
\hline
\end{tabular}

からみると期豫に反して，相觀的なうの方法 は愿分けとしては好ましくない。このつの 方法のうちでは 40 方法が一番すぐれて括 り，癔內の均質性を獲得しているということ ができる。展分けの良さの順位は $4>2>0$ ○である。要するに特定の優占種による檿分 けは必和しも所期の目的に合致せす，やはり 全型成罒によつて形成された相觀（ここには 植被均資度の概念が管まれている）によるの が正しいと思われる。

\section{6. 變量分析による方法の比較}

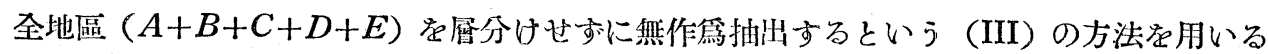

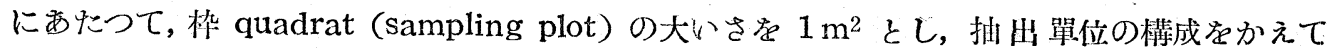

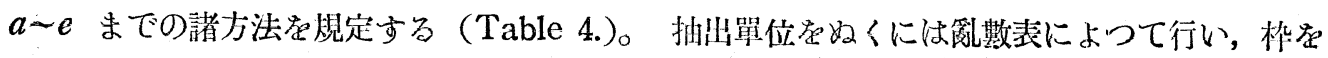
2 こ以上とる場合には閒隔を一定にして $(1 \sim 3 \mathrm{~m})$ ，これ㾟續させる。これらの方法によつて 調查を行つたところ，この群落杂榗成する種類數は 8 , 方法は 5 であつて, 測度には本均被度 居用いてえせ結果から變量分析を行うと Table 5. の上うになる。方を

$$
\begin{aligned}
& F_{\circ}=10.28 / 7.72=1.33 \quad\left(n_{1}=4, n_{2}=28\right) \\
& F_{\circ}=395.85 / 10.28=38.51 \quad\left(n_{1}=7, n_{2}=28\right)
\end{aligned}
$$

ところで $F$ 分布の $1 \%$ の䬯在みると

$$
F=4.07 \quad\left(n_{1}=4, n_{2}=28\right) \quad \therefore F_{\circ}<F
$$




$$
F=3.36 \quad\left(n_{1}=7, \dot{n}_{2}=28\right) \quad \therefore F_{\mathrm{o}}>F
$$

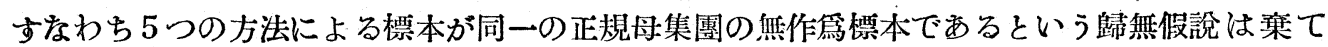
られない。級間本方和は交互作用に比して有意でない。つまり方法間の差異は顯著でないこと になる。ところが盾の間における差は著しく，歸無假說は $1 \%$ の危險率ですててよいことにな る。このように方法間の變動は顛著でないことがわからたが，しかもそれらの間にどの程度の 優劣があるかを average comparable variance ${ }^{7)}$ に上つて比校してみると Table 4.のよう

Table 4. Number of sampling units required for a given accuracy.

\begin{tabular}{c|c|c|c|c}
\hline & \multicolumn{2}{|c|}{ Sampling unit } & $\begin{array}{c}\text { Average } \\
\text { compar- } \\
\text { able } \\
\text { variance }\end{array}$ & $\begin{array}{c}\text { Relative } \\
\text { number of } \\
\text { sampling } \\
\text { units for a } \\
\text { given } \\
\text { accuracy }\end{array}$ \\
\cline { 2 - 5 } of plots & $\begin{array}{c}\text { Sum chains } \\
\text { in }\end{array}$ & \\
\hline a & 1 & & 2.82 & 1.67 \\
b & 2 & 1 & 1.92 & 1.14 \\
c & 3 & 1 & 1.69 & 1.00 \\
d & 2 & 2 & 2.13 & 1.26 \\
e & 2 & 3 & 4.76 & 2.32 \\
\hline
\end{tabular}

Table 5. Analysis of variance

\begin{tabular}{c|r|c|r}
\hline $\begin{array}{c}\text { Variance } \\
\text { due to }\end{array}$ & $\begin{array}{r}\text { Sum of } \\
\text { squares }\end{array}$ & $\begin{array}{r}\text { Degrees } \\
\text { of freedom }\end{array}$ & $\begin{array}{r}\text { Mean } \\
\text { square }\end{array}$ \\
\hline Methods & 30.88 & 4 & 7.72 \\
Species & 2770.98 & 7 & 395.85 \\
Interaction & 287.92 & 28 & 10.28 \\
\hline Total & 3089.78 & 39 & \\
\hline
\end{tabular}

になり，したがつて同一の正確さをうるために右闌のような相對的な抽出數を要することとな

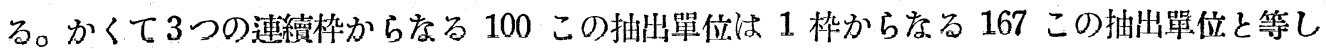
い知識を提供することになる。以上のこと虚頭に入れたうえで, 時間と費用などの點で有利な 方法をえらべばよいのである。

またある特定種類の分布について檢討しようと方る場合, いまたとえばオニシバの地上疃 の分布定とくに密度 (單位面積 $1 \mathrm{~m}^{2}$ ) 学目印として調べてみる。標本抽出は $A, B, C, D, E$

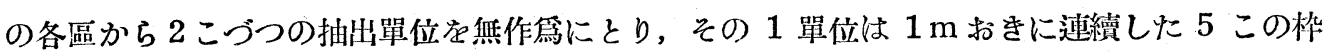
としたとを，泍の間の變動と抽出單位の間の變動變量分析によつてみると,

枠間については $F_{\circ}=12.61\left(n_{1}=4, n_{2}=36\right)$ とこクが $F\left(\alpha=0.05, n_{1}=4, n_{2}=\right.$ $36)=2.63 \therefore F_{\mathrm{o}}>F$.

抽出單位間については $F_{\circ}=3.53\left(n_{1}=36, n_{2}=9\right), F\left(\alpha=0.05, n_{1}=24, n_{2}=9\right)=$ 2.90 かくして $F_{0}>F$ となり，いす机もその變動付有意であるということになる。同㥞に して區間と枠間でみると，

區間では $F_{\circ}=2.43\left(n_{1}=16, n_{2}=4\right), F\left(\alpha=0.05, n_{1}=12, n_{2}=4\right)=5.91, F(\alpha$ $\left.=0.05, n_{1}=24, n_{2}=4\right)=5.77 \quad \therefore F_{\circ}<F$.

枓間では $F_{\circ}=8.23\left(n_{1}=4, n_{2}=16\right), F\left(\alpha=0.05, n_{1}=4, n_{2}=16\right)=3.01$ かくし $\tau F_{\mathrm{o}}>F$.

となり，やはり枠間の變動は有意で西るが，區閒の差は著しくないことになる。このように連 續した枠でもその變動が著しいということは，ここでのォニシバの分布の均質度が高くないこ とを豫想せしめ，また區間のテストからォニシバに關する限り區としては大きな差異を示さな 
いのにそその中ではかなり不均質であることがわかるのである。生なわち、ここでも，西る特 定種類によつて群落の均質性虎論することの危險なことが示された。したがつて８5において

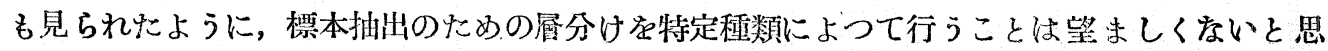
われる。

\section{Summary}

1) I investigated the quantitative method analysing vegetation according to the theory of small samples.

2) It is recognized by most investigators that we ought to use the random sampling in our field survey, but we often based its method on subjective randomizaton.

3) Sampling error is controlled by vegetational homogeneity and sampling ratio. And I could not compare several sampling methods by means of sampling error.

4) The best stratification is the worst clusterization. Those order is expressed by coefficient of interclass correlation $\left(\rho^{\prime}\right)$ and also the quality of sampling method is decided by the coefficient.

5) The stratification by means of a dominant does not coincide with the one by means of the whole physiognomy. The latter is better.

6) The significance of difference between several sampling methods is indicated by analysis of variance. Relative number of sampling units required for a given accuracy according to samling methods is calculated from average comparable variance.

\section{引用文獸}

1）沼田筫： 植物學䆶哂 62, 35 (1949).

2) Pound, R. and F. E. Clements: The phytogeography of Nebraska (1898).

3) Raunkiaer, C.: Bot. Tidsskr. 30, 20 (1909).

4) 沼田真：科學 18, 317 (1918).

5）沼田真：植物學雜誌 (印刷中)。

6）烟村又好, 奥野忠一：標本調查法入阴, 109 (1949)。

7) Johnson, F. A.: Jour. of Forest 47, 292 (1949)。 